\title{
Radical Scavenging Activities of Lagerstroemia speciosa (L.) Pers. Petal Extracts and its hepato-protection in $\mathrm{CCl}_{4^{-}}$ intoxicated mice
}

Bipransh Kumar Tiwary ${ }^{1,2}$, Somit Dutta ${ }^{3}$, Priyankar Dey ${ }^{3}$, Mossaraf Hossain $^{4}$, Anoop Kumar ${ }^{5}$, Sony Bihani ${ }^{5}$, Ashis Kumar Nanda ${ }^{4 *}$, Tapas Kumar Chaudhuri ${ }^{3}$ and Ranadhir Chakraborty ${ }^{1 *}$

\begin{abstract}
Background: Lagerstroemia speciosa (L.) Pers. has medicinal importance. Bioactive phytochemicals isolated from different parts of L. speciosa, have revealed hypoglycemic, antibacterial, anti-inflammatory, antioxidant and hepato protective properties. Despite one report from Philippines detailing the use of $L$. speciosa as curative for fever and as well as diuretic, there is no experimental evidence about the hepatoprotective activity of the flower extracts.

Methods: Several spectroscopic methods, including GC-MS, were used to characterize phytochemicals present in the petal extract of $L$. speciosa. Ethanol extract of petals was evaluated for anti-oxidant and free radical scavenging properties by using methods related to hydrogen atom transfer, single electron transfer, reducing power, and metal chelation. This study has also revealed the in vitro antioxidant and in vivo hepatoprotective properties of petal extract against carbon tetra chloride $\left(\mathrm{CCl}_{4}\right)$-induced liver toxicity in Swiss albino mice. Hepatoprotection in $\mathrm{CCl}_{4}$ -intoxicated mice was studied with the aid of histology and different enzymatic and non-enzymatic markers of liver damage. Cytotoxicity tests were done using murein spleenocytes and cancareous cell lines, MCF7 and HepG2.

Result: GCMS of the extract has revealed the presence of several potential antioxidant compounds, of them $\gamma^{-}$ Sitosterol and 1,2,3-Benzenetriol (Pyrogallol) were the predominant ones. The antioxidants activities of the flowerextract were significantly higher than curcumin (in terms of Nitric oxide scavenging activity; $p=0.0028$ ) or ascorbic acid (in terms of 2,2-Diphenyl-1-Picrylhydrazyl (DPPH) assay; $p=0.0022$ ). The damage control by the flower extract can be attributed to the reduction in lipid peroxidation and restoration of catalase activity. In vitro cytotoxicity tests have shown that the flower extract did not affect growth and survivability of the cell lines. It left beyond doubt that a flower of $L$. speciosa is a reservoir of antioxidant and hepatoprotective agents capable of reversing the damage inflicted by $\mathrm{CCl}_{4}$-intoxication.
\end{abstract}

Conclusion: Results from the present study may be used in developing a potential hepato-protective health drink enriched with antioxidants from Lagerstroemia speciosa (L.) Pers.

Keywords: Antioxidant activity, Lagerstroemia speciosa, Hepatoprotective, CCl

\footnotetext{
* Correspondence: ashis_nanda@hotmail.com; rcnbusiliguri@gmail.com ${ }^{4}$ Department of Chemistry, University of North Bengal, Darjeeling, West Bengal 734013 , India

'Department of Biotechnology, Omics Laboratory, University of North Bengal, Darjeeling, West Bengal 734013, India

Full list of author information is available at the end of the article
} International License (http://creativecommons.org/licenses/by/4.0/), which permits unrestricted use, distribution, and reproduction in any medium, provided you give appropriate credit to the original author(s) and the source, provide a link to the Creative Commons license, and indicate if changes were made. The Creative Commons Public Domain Dedication waiver (http://creativecommons.org/publicdomain/zero/1.0/) applies to the data made available in this article, unless otherwise stated. 


\section{Background}

Lagerstroemia speciosa (L.) is popularly called as "Jarul" in West Bengal, India and it belongs to the family Lythraceae. It is known as Pride of India, and also called Queen's Flowers or Queen Crape Myrtle in English. This plant is widely distributed in the South East-Asian countries, Philippine and India [1]. In India, L.speciosa is highly abundant in the Western and Eastern Ghats and sub-tropical Himalayan regions; flowers are produced in excess by the plant (Additional file 1: Figure S1) for a short period of time but remains unutilized or underutilized. However, the people of South-east Asia used the leaves of $L$. speciosa for the treatment of diabetes mellitus and obesity [2]. The aqueous extract of leaves of $L$. speciosa leaves possess potent antioxidant and free radical scavenging activities by scavenging 2,2-Diphenyl-1Picrylhydrazyl (DPPH) and superoxide radical as well as inhibiting lipid peroxidation [3]. Moreover, the bioactive phytochemicals isolated from different parts of $L$. speciosa, have revealed hypoglycemic, antibacterial, antiinflammatory, antioxidant and hepato protective properties [4-9]. Flowers of several plants were reported as good source of phenolic compounds and antioxidants, and also reported for treating some chronic diseases reported by earlier authors [10]. In Philippines, the decoction of flowers of L. speciosa is used as diuretic and also for treating fevers $[11,12]$. Hence, in this study we opted to explore the pharmacological properties of the flower extract of $L$. speciosa.

The mechanisms of generation of Reactive Oxygen Species (ROS), and scavenging of ROS, operate within living cells. However, damages are inflicted on several cellular macromolecules when there is an imbalance between the generation of ROS and the rate of scavenging. ROS have direct and indirect relationships with oxidation of cellular biomolecules resulting in many health disorders such as neurodegenerative disease, hypertension, inflammation, diabetes, cancer and aging [13]. Living organisms respond to ROS by producing antioxidant enzymes as well as they possess genetically regulated adaptive mechanisms against ROS. However, once the free radicals and ROS overwhelm the regulatory ability of the body, a state of oxidative stress ensues. Supplementation of anti-oxidants, in the normal diet, helps control the ROS-mediated macromolecular damages [14]. The use of natural compounds as complementary and alternative drug is on rise due to the lesser side effects compared to synthetic drugs. At present, natural antioxidants are also used as alternative to synthetic antioxidants in the cosmetic, pharmaceutical and in the food industries [15]. Moreover, presence of considerable quantity of antioxidants in Plant Part Extract (PPE) has always been a dependable clue for the investigators to hypothesize its usefulness in prevention and/or treatment of human diseases in which free radicals and other ROS have been associated. Therefore, hepatoprotective potentiality of PPE is generally evaluated against $\mathrm{CCl}_{4}$ - induced liver damages in murine model $[16,17]$. Several lead chemicals like silymarin, $\beta$-sitosterol, betalain, neoandrographolide, phyllanthin, andrographolide, curcumin, picroside, hypophyllanthin, kutkoside, and glycyrrhizin that have demonstrable hepatoprotective properties, were characterized from several PPEs [18]. High antioxidant activity in flower extracts of different plants such as Tecoma stans, Hibiscus sabdariffa, Calendula officinalis, and Crocus sativus, were screened for hepatoprotective activity by the previous research and proved viable. [19-22].

In the present study, in vitro antioxidant potential of $80 \%$ ethanolic extract of flower of L. speciosa was determined in addition to the quantification of phenolic and flavonoid contents. Prevention of hepatic cell damage by flower-extract in $\mathrm{CCl}_{4}$-intoxicated mice was demonstrated. Cytotoxicity tests of the flower-extract were conducted using murein spleenocytes and cancareous cell lines, MCF7 and HepG2. Since flower extract was found safe in cell-line study, we propose a future development of a suitable health drink from L. speciosa petals, a widely accessible natural bio-resource (Additional file 2: Figure S2).

\section{Methods}

\section{Preparation of plant extract}

The flowers were collected in the month of March (average number of flowers per tree remain higher than February or April) 2014, from Lagerstroemia speciosa (Jarul) trees within the campus of North Bengal University, West Bengal, India. The tree (Accession number- 10512) was authenticated by the Department of Botany, North Bengal University. The petals of the flower were separated and washed thrice with distilled water to remove dust. The washed petals were sun dried and treated at $50{ }^{\circ} \mathrm{C}$ for two hours to eliminate moisture. Dried petals were then milled with a grinder (Maharani, India, Model -Sujata Dynamix). The fine powdered petal was stored in a refrigerator at $-20{ }^{\circ} \mathrm{C}$. One hundred gm of the dried powder was stirred in $1 \mathrm{~L}$ of $80 \%$ ethanol for 1 hour. The mixture was refluxed for 2 hours in soxhlet. After 2 hours, the mixture was centrifuged at $8000 \mathrm{rpm}$ for 15 minutes. Supernatant was collected and concentrated by Rotary evaporator $\left(45^{\circ} \mathrm{C}\right)$ and finally freeze dried. The extract was stored in air-tight vessel at $-20{ }^{\circ} \mathrm{C}$ for further studies.

\section{Determination of antioxidant activity (in vitro) In vitro assays}

The total antioxidant, DPPH radical scavenging, hydroxyl radical scavenging, superoxide radical scavenging, nitric acid radical scavenging, singlet oxygen scavenging, 
reducing power, $\mathrm{Fe}^{2+}$ chelation, peroxynitrite scavenging and hypochlorous acid scavenging activities were determined by following the previous reported methods with minor modification[23, 24].

\section{Determination of erythrocyte-membrane stabilizing activity}

The erythrocyte membrane stabilizing activity was performed by following a standard method as described by Dey et al. [25]. Briefly, varying concentrations of LFE $(0-200 \mu \mathrm{g} / \mathrm{ml})$ was added to the mixture of $50 \mathrm{mM}$ phosphate buffer $(0.5 \mathrm{ml}$; pH 7.2), distilled water $(1 \mathrm{ml})$, $10 \%$ RBC suspension (0.25 ml PBS), $12 \mathrm{mM}$ EDTA $(100 \mu \mathrm{l})$, NBT $(150 \mu \mathrm{l}$ of $1 \%$ solution), and riboflavin $(100 \mu \mathrm{l})$, and kept under bright light for $30 \mathrm{sec}$ and incubated for $30 \mathrm{~min}$ at $50{ }^{\circ} \mathrm{C}$ followed by centrifugation at $1000 \mathrm{rpm}$ for $10 \mathrm{~min}$. The absorbance of the supernatant was measured at $562 \mathrm{~nm}$. The same assay was done with the standard compound, quercetin.

\section{Determination of total phenolic content}

The total phenolics content of LFE was determined using Folin-Ciocalteu method [23]. A standard curve prepared with known quantities of gallic acid $\left(R_{2}=0.9468\right)$ was used to measure the phenolic content of LFE.

\section{Determination of total flavonoid content}

The total flavonoids content was determined with aluminium chloride $\left(\mathrm{AlCl}_{3}\right)$ described by Hazra et al. [23]. The flavonoid content was ascertained from the standard curve prepared with known quantities of quercetin $(R 2=0.9947)$.

\section{Determination of cytotoxicity MTT Cytotoxicity assay for murine spleenocytes}

The spleen was separated from a sacrificed Swiss albino mice. Cell suspension $\left(2 \times 10^{6} \mathrm{cells} / \mathrm{ml}\right)$ was prepared in RPMI- 1640 medium supplemented with $50 \mathrm{U} / \mathrm{ml}$ penicillin, $50 \mathrm{U} / \mathrm{ml}$ streptomycin, $50 \mathrm{U} / \mathrm{ml}$ nystatin and $10 \%$ FBS as per reported method.EZcount ${ }^{\mathrm{T}}$ MTT Cell Assay Kit (HiMedia CCK003) was used, following manufacturers instruction, to determine the cytotoxicity. The percentage of cytotoxicity was calculated using the formula: $(\mathrm{Y}-\mathrm{X}) \div \mathrm{Y} \times 100$ [where $\mathrm{Y}$ is the mean optical density of the control (DMSO treated cells); and $\mathrm{X}$ is the mean optical density of the treated cells with LFE].

\section{Determination of effect of LFE on cancerous cells following MTT assay}

The effect of LFE on cancerous cell lines was measured using a known MTT-assay protocol as described by Denizot \& Lang [26] but with minor modifications. Two different cancerous cells, human breast adenocarcinoma cell line (MCF 7) and human hepatocarcinome cell line
$\left(\mathrm{HepG}_{2}\right)$ were obtained from National Centre for Cell Science, Pune, India. Both the cell lines were treated with different concentrations of LFE in this study.

\section{Determination of in-vivo antioxidant activity of LFE Maintenance of Swiss albino mice}

Swiss albino mice (6-8 weeks) of both sexes (equal number of mice from each sex) were maintained individually (one animal per cage in order to prevent aggression, if any, of one towards the other of the same sex or opposite) inside the cage bins (Tarson, India) with rice husk bedding in the animal enclosure of the Department of Biotechnology, University of North Bengal by maintaining proper photoperiod $(12 \mathrm{~h})$, temperature $\left(25 \pm 2^{0} \mathrm{C}\right)$ and humidity $(55 \pm$ $5 \%)$. The animals were provided pellet food (Pranav Agro Pvt. Ltd. India) and filtered (Aquaguard Eureka Forbes) tap water ad libitum. All experiments were approved by the ethical committee University of North Bengal (NO.840/ac/ 04 CPCSEA; date: 15.09.2010).

\section{Determination of acute toxicity of LFE}

Acute toxicity of LFE was studied following OECD in full guidelines (test 423: Acute oral toxicity - Acute toxic class method; 2002) [OECD Library]. Mice were divided into four groups $(n=6)$ and fasted overnight prior to the experiment. LFE was administered orally at 250, 500, 1000 and $1500 \mathrm{mg} / \mathrm{kg}$ body weight (bw) dose. The experimental mice were carefully observed for development of any clinical or toxicological symptoms at different time-period, 0.5, 2, 4, 8, 24 and $48 \mathrm{~h}$.

\section{$\mathrm{CCl}_{4}$ intoxication of experimental mice followed by treatment with LFE or silymarin}

Swiss albino mice, male or female, were randomly distributed into 5 groups $(n=6)$ and for consecutive 10 days they received treatments once per day as per design illustrated below.

The group that received normal saline was used as control. The other groups were : (i) $\mathrm{CCl}_{4}$ group which received 1:1 (v/v) $\mathrm{CCl}_{4}$ in olive oil; (ii) Silymarin group that received $1: 1(\mathrm{v} / \mathrm{v}) \mathrm{CCl}_{4}$ in olive oil and $100 \mathrm{mg} / \mathrm{kg}$ bw silymarin; (iii) Lower dose (LD) of LFE treated group which received $1: 1(\mathrm{v} / \mathrm{v}) \mathrm{CCl}_{4}$ in olive oil and $100 \mathrm{mg} / \mathrm{kg}$ bw LFE; and (iv) higher dose (HD) of LFE treated group which received 1:1 (v/v) $C_{4}$ in olive oil and $250 \mathrm{mg} / \mathrm{kg}$ bw LFE.

After cardiac punctures of the anesthesized mice (for collection of blood) made on 11th day (i.e. $24 \mathrm{~h}$ after the last treatment), the animals were sacrificed. Blood was allowed to clot for $60 \mathrm{~min}$ at room temperature $\left(20{ }^{\circ} \mathrm{C}\right)$ and then serum was separated by centrifuging at $1000 \mathrm{rpm}$ for $5 \mathrm{~min}$. Serum was used to study marker enzymes specific to liver. The liver was surgically removed from the anesthesized animals after the cardiac 
puncture and before the final sacrifice. Surgically separated livers were washed with double distilled water to remove blood and homogenized tissues were used for antioxidant enzymatic assays. Liver tissues were collected in Bouin's solution for histological studies.

\section{Liver function test}

The serum samples from each group were used to study Acid Phosphotase (ACP), Alkaline phosphatise (ALP), Aspartate aminotransferase (AST), Alanine aminotransferase (ALT) and total protein using commercially available kits (Biosystems; 11548, 11592, 11830, 11832, 11800).

\section{Determination of Catalase activity (CAT), lipid peroxidation activity (LPO) and reduced Glutathione (GSH) determination}

CAT activity was measured by the method described by earlier authors [27]. Lipid peroxidation was quantified by thiobarbituric acid (TBA) reaction with malondialdehyde (MDA). The amount of MDA was assessed by measuring the absorbance of supernatant at $540 \mathrm{~nm}$ at room temperature against an appropriate blank [27]. Glutathione was determined by the modified method of Ellman [28].

\section{Histological studies}

Livers were removed from the animals of the in vivo experiments after collection of blood and were fixed overnight in $10 \%$ buffered formalin. The samples were subjected to dehydration and the embedded in paraffin. Thin sections $(4 \mu \mathrm{m})$ of the paraffin embedded livers were cut by microtome and then de-waxed in xylene, rehydrated in a series of different grades of alcohol and then washed with distilled water for $5 \mathrm{~min}$. Subsequently, the sections were stained with haematoxylin for $40 \mathrm{~s}$ and counterstained with eosin for $20 \mathrm{~s}$. The sections were dehydrated in graded alcohol series and washed in xylene. The slides were observed using Magnus trinocular microscope MLX-TR (Olympus microscopes) for signs of necrosis, portal inflammation, vascular congestion, fatty infiltration, vacuolar degeneration, leukocyte infiltration, loss of structure of hepatic nodules and so forth.

\section{Spectroscopic characterization of LFE}

All UV-vis spectra were recorded in the range of 200$800 \mathrm{~nm}$ at room temperature with UV-1700 Spectrometer (Jasco Make, Tokyo, Japan). IR spectra of LFE obtained with Shimadzu FT-IR (Japan) were monitored by mulling in $\mathrm{KBr}$. The Energy-dispersive Spectroscopy (EDS) was done with JEOL Model JED - 2300 to analyse the presence of different elements in the LFE.

\section{GC-MS analysis of LFE}

LFE was dissolved in $n$-hexane and the mixture was centrifuged thrice at 12,000 rpm for $15 \mathrm{~min}$. The clear supernatant was used for GC-MS analysis. Agilent 5975 CGCMS system (Agilent Technologies, USA) attached with HP- $5 \mathrm{~ms}$ Capillary Column $(30 \mathrm{~m} \times 0.25 \mathrm{~mm}$ i.d. $\times$ $0.25 \mu \mathrm{m}$ film thickness) and equipped with inert MSD triple axis mass detector condition edation trap $200{ }^{\circ} \mathrm{C}$, transfer line $280{ }^{\circ} \mathrm{C}$, electronenergy $70 \mathrm{eV}$ (vacuum pressure-2.21e0.5 Torr) was used for analysis. The carrier gas, helium, was used at a flow rate of $1 \mathrm{ml} / \mathrm{min} .2 \mathrm{ml}$ sample was injected in a split less mode. The column temperature was set at $60{ }^{\circ} \mathrm{C}$ for $1 \mathrm{~min}$ followed by $5{ }^{\circ} \mathrm{C} / \mathrm{min}$ up to $250{ }^{\circ} \mathrm{C}$. The major and essential compounds in LFE were identified by the retention times and mass fragmentation patterns using Agilent Chem Station integrator and the database of National Institute of Standard and Technology (NIST) with a MS library version2011.

\section{Statistical analysis}

Assays were carried out in triplicate for all the experiments. The results are expressed as mean and standard deviation values (mean $\pm \mathrm{SD}$ ). Differences between means were determined by the analysis of variance (ANOVA), which were analyzed with SPSS v. 1 . Paired ' $\mathrm{t}$ ' test was done using Ky plot 5.0 (kyplot.software.informer.com/5.0/).

\section{Results}

\section{In vitro antioxidant activity}

The free radical scavenging activities of LFE in dose dependent manner and the differences in activities compared with standard compounds per test under varying doses were statistically interpreted (Fig $1 \mathrm{a}-\mathrm{k}$ ). The half maximal inhibitory concentration $\left(\mathrm{IC}_{50}\right)$ of LFE or the corresponding reference compounds is shown in Table 1. LFE showed lower $\mathrm{IC}_{50}$ value than ascorbic acid, mannitol and curcumin in DPPH $(p=0.0022)$, hydroxyl radical $(p=0.00001)$ and nitric oxide free radical $(p=0.002)$ scavenging assays respectively; and found comparable with superoxide radical shown by quercetin $(p=0.52)$ and total antioxidant activity shown by trolox $(p=0.6)$.

\section{Determination of reducing power}

The reducing power of the LFE was determined. It was found that reducing capacity of the LFE was dosedependent and comparable to the reference compound, ascorbic acid (Fig. 1k).

\section{Determination of Phenol content and flavonoids in LFE}

The total amount of phenolic content present in ethanolic extracts of $L$. specioa was found to be $44.66 \mathrm{mg} / \mathrm{ml}$ gallic acid equivalent per $100 \mathrm{mg}$ plant extract. The total flavonoid content of the LFE was $45.33 \pm 0.004 \mathrm{mg} / \mathrm{ml}$ quercetin equivalent per $100 \mathrm{mg}$ plant extract. 

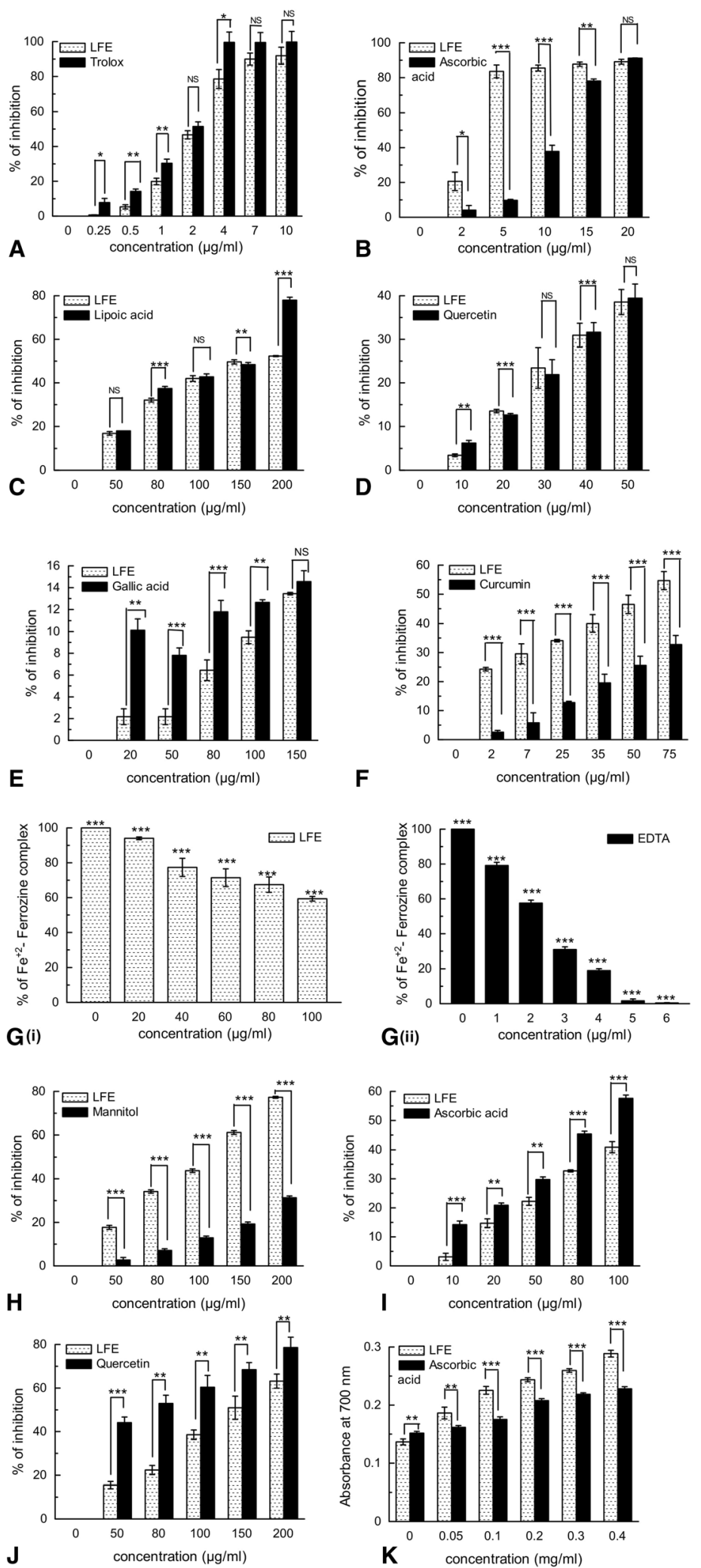

Fig. 1 (See legend on next page.) 
(See figure on previous page.)

Fig. 1 Free radical scavanging activity of Lagerstroemia flower extract (LFE). a Total antioxidant assay; b DPPH radical scavenging activity; c Singlet oxygen scavenging activity; d Superoxide radical scavenging activity; e Peroxynitrite radical scavenging activity; f Nitric oxide scavenging activity; $\mathbf{g}$ (i) and (ii). Fe chelation activity; $\mathbf{h}$ Hydroxy radical scavenging; i Hypocholorous radical scavenging activity; $\mathbf{j}$ Erythrocyte membrane stabilizing activity; and $\mathbf{k}$ Reducing power assay. Paired ' $\mathrm{t}$ ' test was done to interpret significant difference between effect of LFE and the known standard; $*^{* *}, p<0.001 ; * *, p<0.01$; and ${ }^{*}, p<0.05$

\section{Cytotoxicity and MTT assay}

Treatment of cancerous cell lines, MCF-7 and HepG2, with LFE at different concentration from 0 to $100 \mu \mathrm{g} / \mathrm{ml}$ showed no effect on the growth and survivability. Cytotoxicity of LFE was also evaluated by using murine spleenocytes and cytotoxic effect was not observed up-to treatment of $200 \mathrm{ug} / \mathrm{ml}$ of LFE in spleenocytes.

\section{Hepatoprotective activity of LFE}

Acute toxicity study In the experimental mice, no signs of mortality were observed up to $1500 \mathrm{mg} \mathrm{LFE} / \mathrm{kg} \mathrm{BW}$ (highest dose used in this study). So, dosages of $100 \mathrm{mg} / \mathrm{kg}$ (low dose) and $250 \mathrm{mg} / \mathrm{kg}$ (high dose) were selected for the in-vivo hepatoprotective treatment.

\section{Body and liver weight changes}

Changes of the body and liver weight after the treatment of LFE are shown in Table 2. Significant weight loss was observed in $\mathrm{CCl}_{4}$ treated group whereas weight gain was observed in the control and silymarin group; but interestingly no significant weight gain was noticed in the experimental group. Hence, the percentage body weight change of $\mathrm{CCl}_{4}$ treated group was highest compared to the control, standard and experimental group.

\section{Liver marker enzyme and biochemical parameters}

In this study, liver marker enzymes were estimated to obtain a clear picture of the medicinal potentiality of LFE in case of hepatic injury. The effects of $\mathrm{CCl}_{4}$ and subsequent administration of silymarin and LFE on the Acid phosphatase (ACP), Alkaline phosphatase (ALP), Aspartate transaminase (AST), Alanine transaminase (ALT) and protein level and percentage changes were shown in the Table 3. The levels of all the marker enzymes tested were found to be increased (except protein) on $\mathrm{CCl}_{4}$ administration and subsequently decreased with silymarin or LFE treatment.

\section{Lipid peroxidation (LPO), enzymatic catalase (CAT), and non-enzymatic reduced glutathione (GSH) level antioxidant assays}

Significant inhibitions of LPO $(p \leq 0.001)$, enzymatic CAT $(p \leq 0.005)$ and non - enzymatic GSH $(p \leq 0.001)$ occurred in $\mathrm{CCl}_{4}$ intoxicated mice when compared with control (Fig. 2). LFE treatment enabled significant increase in $\%$ inhibition of LPO $(p \leq 0.001)$, CAT $(p \leq 0.01)$ and $\mathrm{GSH}(p \leq 0.01)$ compared to $\mathrm{CCl} 4$ treated mice (Fig. 2a).On the other hand, silymarin treatment has similarly led to significant increase in \% inhibition of LPO $(p \leq 0.001)$, CAT $(p \leq 0.01)$ and GSH $(p \leq 0.001)$ compared to $\mathrm{CCl} 4$ treated mice (Fig. $2 \mathrm{~b}$ ).

\section{Histological comparison between liver tissue of $\mathrm{CCl}_{4}$ - intoxicated and $\mathrm{CCl}_{4}$-intoxicated but silymarin or LFE treated mice}

The histological injury was observed and counts in the liver tissue of $\mathrm{CCl}_{4}$-intoxicated and $\mathrm{CCl}_{4}$-intoxicated but silymarin or LFE treated (low dose or high dose) mice were represented as injury score (Additional file 3: Table S1).

Table 1 Half maximal inhibitory concentration $\left(\mathrm{IC}_{50}\right)$ value of LFE and standards compounds for different free radical scavenging

\begin{tabular}{|c|c|c|c|c|c|}
\hline S.No & Assay & Standard compound & Calculated $\mathrm{IC}_{50}$ Standard & Calculated $\mathrm{IC}_{50} \mathrm{LFE}$ & $\begin{array}{l}\text { 2-sample } t \text { test } \\
\text { ( } p \text { value) }\end{array}$ \\
\hline 1 & $\mathrm{DPPH}$ & Ascorbic acid & $11.30 \pm 1.23$ & $3.23 \pm 0.7$ & 0.002 \\
\hline 2 & Superoxide radical & Quercetin & $63.83 \pm 2.5$ & $65.57 \pm 3.4$ & 0.52 \\
\hline 3 & Singlet Oxygen & Lipoic acid & $131.21 \pm 8.3$ & $162.72 \pm 4.2$ & 0.02 \\
\hline 4 & Total antioxidant assay & Trolox & $3.26 \pm 1.7$ & $3.89 \pm 0.5$ & 0.6 \\
\hline 5 & Hypochlorous scavenging activity & Ascorbic acid & $87.72 \pm 4.9$ & $124.03 \pm 9.1$ & 0.009 \\
\hline 6 & Hydroxyl radical & Mannitol & $332.93 \pm 3.5$ & $124.75 \pm 5.8$ & 0.00001 \\
\hline 7 & Nitric oxide & Curcumin & $109.60 \pm 6.1$ & $58.86 \pm 7.5$ & 0.0028 \\
\hline 8 & Peroxynitrite radical & Gallic acid & $591.65 \pm 13.9$ & $500 \pm 12.2$ & 0.003 \\
\hline 9 & Erythrocyte membrane stabilizing activity & Quercetin & $94.74 \pm 5.5$ & $152.48 \pm 4.9$ & 0.0008 \\
\hline 10 & Fe chelation & EDTA & $25.37 \pm 3.5$ & $118.771 \pm 12.4$ & 0.0062 \\
\hline
\end{tabular}


Table 2 Comparision of body and liver weight of $\mathrm{CCl}_{4}$ induced with control (untreated), LFE treated and silymarin treated groups

\begin{tabular}{llllll}
\hline Parameters (units) & Control & $\mathrm{CCl}_{4}$ & Sylimarin & $\begin{array}{l}\text { LFE Low Dose } \\
(100 \mathrm{mg} / \mathrm{kg} \text { body weight) }\end{array}$ & $\begin{array}{l}\text { LFE High Dose } \\
(250 \mathrm{mg} / \mathrm{kg} \text { body weight) }\end{array}$ \\
\hline Initial body weight (g) & $21.70 \pm 0.48$ & $22.31 \pm 0.26$ & $22.37 \pm 0.46$ & $22.03 \pm 0.46$ & $22.07 \pm 0.71$ \\
Final body weight (g) & $23.28 \pm 0.42$ & $20.81 \pm 0.74$ & $23.31 \pm 0.39$ & $22.38 \pm 0.70$ & $22.17 \pm 0.66$ \\
Body weight change (\%) & 6.79 & 6.74 & 4.20 & 1.59 & 0.45 \\
Liver weight (g) & $4.86 \pm 0.11$ & $5.46 \pm 0.09$ & $4.59 \pm 0.22$ & $5.03 \pm 0.14$ & $4.90 \pm 0.08$ \\
Relative liver weight (g) & 20.88 & 26.24 & 19.69 & 22.48 & 22.10 \\
\hline
\end{tabular}

The haematoxalin - eosin staining of liver tissue sections clearly displayed differences resulting from damages inflicted by $\mathrm{CCl}_{4}$. The liver tissue sections of the control group showed well maintained hepatocellular integrity, healthy cellular architecture, and clear cytoplasm with prominent nucleus (Fig 3a) while signs of tissue damages were evident in $\mathrm{CCl}_{4}$ treated mice liver sections (Fig. 3b) including signs of fibrosis (Fig. $3 \mathrm{c}$ and Additional file 4: Figure S4). On treatment of silymarin, the signs of healing of the damaged tissue were evident (Fig. 3d). Low dose treatment $(100 \mathrm{mg} / \mathrm{kg}$ body weight) of LFE helped to reduce the damage but to a lesser extent when compared to silymarin treatment (Fig. 3e). Comparatively, treatment with higher dose of LFE (250 mg/kg body weight) has shown better recovery (Fig. $3 \mathrm{f}$ ). Total damage score was very high in $\mathrm{CCl}_{4}$ intoxicated mice (23) compared to control (2), silymarin group (7) and LFE treated group LD (16) and HD (9). (Additional file 3: Table S1).

\section{Furier Transform Infrared (FTIR) spectroscopy}

On analyses of FTIR spectra several intense peaks corresponding to the defined functional groups were noted. It indicated the presence of alcohols, phenols, carboxylic acid, within range of $3000-3550 \mathrm{~cm}^{-1}$, aldehydes, ketones, carboxylic acid at $1708 \mathrm{~cm}^{-1}$, amide bonds at $1604 \mathrm{~cm}^{-1}$, amines, sulfones, sulfomyl chloride at $1316 \mathrm{~cm}^{-1}$, alcohols, and carboxylic acids at $1176 \mathrm{~cm}^{-1}$ (Additional file 5: Figure S5).

\section{Energy dispersion spectroscopy}

The elemental composition of the LFE was determined by EDS (Additional file 6: Figure S6). The intense signals in the range of $0-0.5 \mathrm{keV}$-strongly suggests that carbon and oxygen were the major elements.Additionally, peak for potassium element was also found. Again the ED spectra have revealed absence of heavy metal.

\section{GC-MS analysis}

GC-MS analysis (Additional file 7: Figure S7) of LFE has enabled identifying several small compounds of diverse chemical nature (Table 4), of which many of them are reported to possess distinct and definitive pharmacological activities.

\section{Discussion}

Interest in antioxidants of natural origin as food and health supplements has increased much because of their potential to prevent and to reduce the risk of several diseases without any toxic effect [29]. The plant species, $L$. speciosa (L.) Pers, in the 1990's, has attracted attention of the scientists worldwide because of its special therapeutic properties particularly for diabetes, obesity, and renal disorders $[30,31]$. Although, different vegetative parts as well as seeds of this plant were explored for potential antioxidant agents [6, 7] but, only a single report exists that has mentioned the antioxidant activity of $L$. speciosa flowers [32]. Generally, antioxidant activities

Table 3 Extent of variation(s) in biochemical and enzymatic parameters in different groups treated with $\mathrm{CCl}_{4}$ or silymarin or LFE. The data represents mean \pm SD of six independent observations

\begin{tabular}{|c|c|c|c|c|c|}
\hline Parameters (Units) & Control & $\mathrm{CCl}_{4}$ & Silymarin & LFE (Low Dose) & LFE (High Dose) \\
\hline$\overline{A L P}$ (K.A.) & $7.75 \pm 0.17$ & $28.52 \pm 1.87^{* *}$ & $10.50 \pm 1.61^{\mathrm{NS}}$ & $18.48 \pm 1.33 * *$ & $12.99 \pm 0.22 * *$ \\
\hline ACP (K.A.) & $4.06 \pm 0.48$ & $7.35 \pm 0.11^{* *}$ & $16.55 \pm 0.43 * *$ & $14.35 \pm 0.34 * * *$ & $10.79 \pm 0.50 * *$ \\
\hline AST (u/ml) & $61.78 \pm 2.48$ & $133.21 \pm 3.94^{* * *}$ & $\underset{* * *}{75.26 \pm 3.29}$ & $126.27 \pm \underset{* * *}{ \pm 2.73}$ & $86.12 \pm 4.29$ \\
\hline ALT (u/ml) & $51.27 \pm 1.58$ & $\underset{* * *}{138.29 \pm 4.83}$ & $\underset{* * *}{68.28 \pm 3.97}$ & $109.93 \pm 3.75$ & $\underset{* * *}{81.28 \pm 4.17}$ \\
\hline Protein (g/dl) & $7.61 \pm 0.27$ & $4.42 \pm 0.30 *$ & $7.40 \pm 0.30^{\mathrm{NS}}$ & $4.74 \pm 0.10 * *$ & $5.50 \pm 0.19 *$ \\
\hline
\end{tabular}

N.S. $P>0.05$ When compared with control, ${ }^{*} P<=0.05$ When compared with control, ${ }^{* *} P<=0.01$ When compared with control, ${ }^{* * *} P<=0.001$ When compared with control 

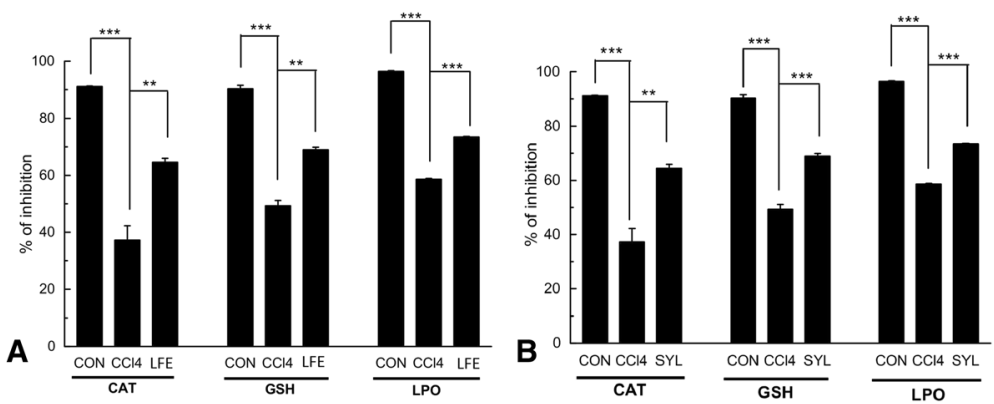

Fig. 2 Hepatoprotective effect of Lagerstroemia flower extract (LFE) or silymarin (SYL) in CCI treated mice. a Protective effect of LFE on catalase (CAT) activity, reduced glutathione (GSH) and Lipid peroxidation (LPO) in $\mathrm{CCl}_{4}$ treated mice. b Protective effect of silymarin on catalase (CAT) activity, reduced glutathione (GSH) and Lipid peroxidation (LPO) in $\mathrm{CCl}_{4}$ treated mice group. Comparisons were made with (i) control (CON); (ii) $\mathrm{CCl}_{4}$ treated (no protection) (CON) for statistical inference (' $\mathrm{t}$ ' test for paired comparison) to interpret significant difference (Data represented as Mean \pm SD of six observations. ${ }^{*}, p<0.05,{ }^{* *}, p<0.01$ and ${ }^{* *}, p<0.001$.)

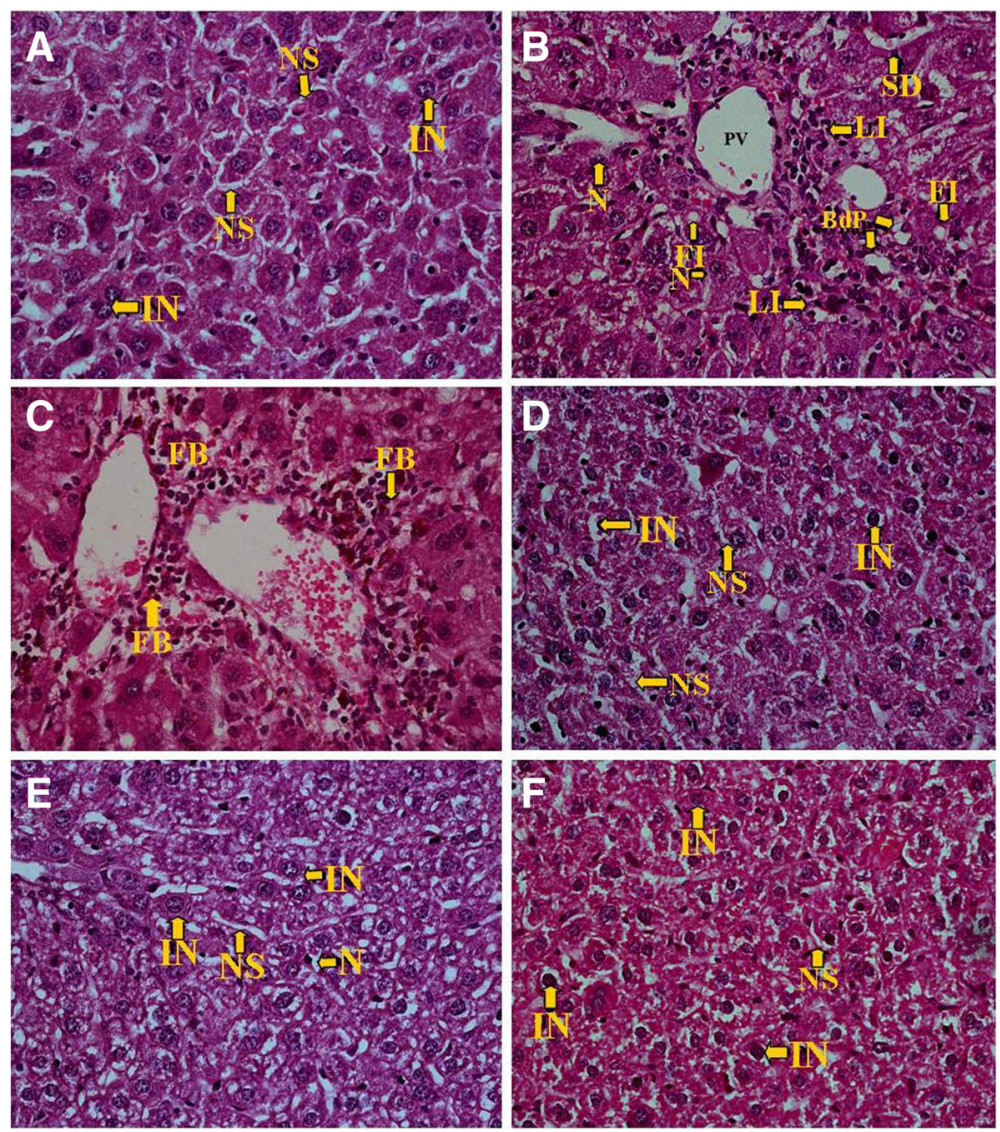

Fig. 3 Photomicrographs: histological sections of mice liver samples. Pictures were taken under original magnification of 400X. a Liver section from the control group demonstrating normal liver architecture with intact nucleus (IN), and normal sinusoids (NS); $\mathbf{b}$ Liver section from CCl 4 induced damaged liver demonstrating highly deformed liver architecture with round congested portal vein (PV), bile duct proliferation (BdP), fatty lesion due to intensive fatty infiltration (FI), sign of necrosis (N), dilated sinusoid (SD), leukocyte infiltration (LI); $\mathbf{c}$ Liver section from $\mathrm{CCl}_{4}$ induced damaged liver demonstrating fibrosis (FB); $\mathbf{d}$ Liver section from Silymerin treated group demonstrating improved hepato-cellular architecture with normal sinusoids and intact nucleus (IN); e Liver section from low dose LFE (100 mg/kg of body weight) treated group showing sign of necrosis (N) [of lesser degree compared to the $\mathrm{CCl}_{4}$ group]; $\mathbf{f}$ Liver section from high dose LFE (250 mg/kg of body weight) treated group showing improved liver architecture with normal sinusoids (NS) and intact nucleus (IN) 
Table 4 Phytochemicals identified in the ethanolic extract of the flower of L.speciosa by GC-MS analysis

\begin{tabular}{|c|c|c|c|}
\hline SI. No. & Compound name & Chemical formula & RT \\
\hline 1. & 2,6-Nonadienal, 3,7-dimethyl- & $\mathrm{C}_{11} \mathrm{H}_{18} \mathrm{O}$ & 5.60 \\
\hline 2. & N-[4-(4-Chlorophenyl)isothiazol-5-yl)-1-methylpiperidin-2-imine & $\mathrm{C}_{15} \mathrm{H}_{16} \mathrm{ClN}_{3} \mathrm{~S}$ & 5.84 \\
\hline 3. & 2-Furancarboxaldehyde, 5-methyl- & $\mathrm{C}_{6} \mathrm{H}_{6} \mathrm{O}_{2}$ & 6.77 \\
\hline 4. & Formamide, N-[1-[(1-cyano-2-methylpropyl) hydroxyamino]-2-methylpropyl]- & $\mathrm{C}_{10} \mathrm{H}_{19} \mathrm{~N}_{3} \mathrm{O}_{2}$ & 6.94 \\
\hline 5. & Oxazolidine, 2,2-diethyl-3-methyl- & $\mathrm{C}_{8} \mathrm{H}_{17} \mathrm{NO}$ & 6.74 \\
\hline 6. & Oxirane, [(hexadecyloxy)methyl]- & $\mathrm{C}_{19} \mathrm{H}_{38} \mathrm{O}_{2}$ & 9.27 \\
\hline 7. & 2H-Tetrazole, 2-(1,3-dioxolan-4-ylmethyl)- & $\mathrm{C}_{6} \mathrm{H}_{10} \mathrm{~N}_{4} \mathrm{O}_{2}$ & 9.76 \\
\hline 8. & Furylhydroxymethyl ketone & $\mathrm{C}_{6} \mathrm{H}_{6} \mathrm{O}_{3}$ & 9.94 \\
\hline 9. & 2,3-Dimethylfumaric acid & $\mathrm{C}_{6} \mathrm{H}_{8} \mathrm{O}_{4}$ & 10.46 \\
\hline 10. & 4H-Pyran-4-one, 2,3-dihydro-3,5-dihydroxy-6-methyl- & $\mathrm{C}_{6} \mathrm{H}_{8} \mathrm{O}_{4}$ & 11.63 \\
\hline 11. & 2-Furanone, 3,4-dihydroxytetrahydr & $\mathrm{C}_{4} \mathrm{H}_{6} \mathrm{O}$ & 12.96 \\
\hline 12. & d-Ribo-hexos-3-ulose & $\mathrm{C}_{6} \mathrm{H}_{10} \mathrm{O}_{6}$ & 13.62 \\
\hline 13. & 5-Hydroxymethylfurfural & $\mathrm{C}_{6} \mathrm{H}_{6} \mathrm{O}_{3}$ & 13.97 \\
\hline 14. & d-Mannose & $\mathrm{C}_{6} \mathrm{H}_{12} \mathrm{O}_{6}$ & 14.89 \\
\hline 15. & Tetradecanoic acid, 2-hydroxy- & $\mathrm{C}_{14} \mathrm{H}_{28} \mathrm{O}_{3}$ & 15.25 \\
\hline 16. & 5-(Hydroxymethyl)-2-(dimethoxymethyl) furan & $\mathrm{C}_{8} \mathrm{H}_{12} \mathrm{O}_{4}$ & 15.87 \\
\hline 17. & 1,2,3-Benzenetriol (Pyrogallol) & $\mathrm{C}_{6} \mathrm{H}_{6} \mathrm{O}_{3}$ & 17.93 \\
\hline 18. & Desulphosinigrin & $\mathrm{C}_{10} \mathrm{H}_{17} \mathrm{NO}_{6} \mathrm{~S}$ & 19.49 \\
\hline 19. & D-Allose & $\mathrm{C}_{6} \mathrm{H}_{12} \mathrm{O}_{6}$ & 20.64 \\
\hline 20. & 3-tert-Butyl-4-hydroxyanisole (also known as 3-BHA, which is a potent antioxidant) & $\mathrm{C}_{11} \mathrm{H}_{16} \mathrm{O}_{2}$ & 22.66 \\
\hline 21. & Benzoic acid, 4-hydroxy-3,5-dimethoxy- (also known as Syringic acid) & $\mathrm{C}_{9} \mathrm{H}_{10} \mathrm{O}_{5}$ & 28.09 \\
\hline 22. & n-Hexadecanoic acid & $\mathrm{C}_{16} \mathrm{H}_{32} \mathrm{O}_{2}$ & 31.03 \\
\hline 23. & Hexadecanoic acid, ethyl ester & $\mathrm{C}_{18} \mathrm{H}_{36} \mathrm{O}_{2}$ & 31.70 \\
\hline 24. & 9,12-Octadecadienoic acid (Z, Z)- (also known as Linoleic acid) & $\mathrm{C}_{18} \mathrm{H}_{32} \mathrm{O}_{2}$ & 34.23 \\
\hline 25. & 9,12,15-Octadecatrienoic acid, 2,3-dihydroxypropyl ester, (Z, Z, Z)- & $\mathrm{C}_{21} \mathrm{H}_{36} \mathrm{O}_{4}$ & 34.34 \\
\hline 26. & $\gamma$-Sitosterol & $\mathrm{C}_{29} \mathrm{H}_{50} \mathrm{O}$ & 52.51 \\
\hline
\end{tabular}

present in the plant extracts are studied with reference to hydrogen atom transfer (HAT), single electron transfer (ET), reducing power, and metal chelation assays [33]. Therefore, in the screening of antioxidant activity of LFE, it showed strong scavenging capacity against DPPH radical, singlet oxygen, superoxide radical, NOradicals and hydroxyl radical in a dose dependent way (Fig. 1 and Table 1). Total antioxidant activity of LFE's was found similar to trolox (standard compound) in neutralizing the radical cation $\mathrm{ABTS}^{\circ+}$ (Fig. 1a). Hypochlorous acid is known to get produced from the site of inflammation resulting from the oxidation of $\mathrm{Cl}^{-}$ions by the neutrophil enzyme, myelo-peroxidase. The radical, $\mathrm{HOCl}$ is known to degrade heme-prosthetic group and inactivate the antioxidant enzyme, catalase. The $\mathrm{HOCl}$ scavenging activity of the LFE corresponded with the inhibition of catalase deactivation (Fig 1i and Table 1).

Reducing power is also one of the measures to confirm antioxidant activity and thus could serve as an indicator of potential antioxidant activity [34]. In this study, the reducing power of LFE was found comparable with standard compound ascorbic acid (Fig. 1k). It was conjectured that compounds with chelating activity can inhibit lipid peroxidation by stabilizing transition metals. Our results have indicated that the chelating effect of LFE would be at least partly beneficial in protecting against oxidative damage, but not efficient as EDTA. The results also showed that LFE could protect erythrocyte membrane stabilizing activity better than the standard compound quercetin by means of scavenging superoxide radicals (Table 1 ).

Our results revealed the presence of high contents of phenolic and flavonoids in LFE, which is similar to an earlier report [32]. Phenolics and flavanoid compounds are capable of scavenging singlet oxygen and various free radicals [35]. They may also help to prevent diseases associated with oxidative stress, such as atherosclerosis, cancer and neurodegenerative diseases [36]. In this study, results of cytotoxic activity in murine spleenocytes and human MCF 7 and HepG2 cell lines have shown no 
inhibition in growth, thus ruling out toxic effect of LFE on mammalian cells (data not shown). Taken together all the results, we may say with caution that LFE is perhaps safe for human consumption.

Moreover, it is essential to confirm in vitro results with in vivo assays. A common hepatotoxin, $\mathrm{CCl}_{4}$, is generally used to induce hepatic damage in animal model to understand the extent of tissue damages for correlating conditions that happen in human beings during acute hepatitis [37]. In this perspective, we have used mice as a model animal to check $\mathrm{CCl}_{4}$-induced hepatoxicity and subsequent hepato-protection with the aid of LFE. When mice is fed with $\mathrm{CCl}_{4}$, cytochrome $\mathrm{P} 450$ (liver enzyme) metabolises it to two trichloromethyl radicals, $\mathrm{CCl}_{3}$ and $\mathrm{CCl} 3 \mathrm{OO}$, by cleaving the carbon chloride bond of carbon tetrachloride [38]. The trichloromethyl radicals generated from $\mathrm{CCl}_{4}$ initiate free radical-mediated lipid peroxidation, which in turn leads to the accumulation of oxidation products causing apoptosis or necrosis in liver tissues [39]. We have found that LFE can heal $\mathrm{CCl}_{4}$ induced damaged liver in mice (Fig. 3). In case of acute hepatic damage (due to toxicity) in human beings, silymarin, an antioxidant flavanoid, is prescribed as a healing agent $[40,41]$. The same compound, sylmarin, was used as the control preventive agent in our experiment. Results have shown that exposure to $\mathrm{CCl}_{4}$ caused significant difference in body, liver and relative liver weights with respect to the control group. Reduction in body weight and increment in liver weight took place in $\mathrm{CCl}_{4}$ intoxicated mice with respect to the control group. Due to $\mathrm{CCl}_{4}$ toxicity, relative liver weight of $\mathrm{CCl}_{4}$ treated mice was found much higher than the control (Table 2). It is known that liver weight generally increases due to hepatic damage inflicted by trichloromethyl radical [42]. Liver weight may also increase due to consequent liver fibrosis; and hypertrophy could therefore arise due to accumulation of glycogen in hepatocytes [43]. Hence, changes in body and liver weight after $\mathrm{CCl}_{4}$ intoxication provides direct evidence to the overall hepatic damage. Treatment with LFE (250 mg/kg body weight) has significantly prevented subsequent liver enlargement in mice. Lowering of liver or relative liver weight in LFE treated mice compared to $\mathrm{CCl}_{4}$ group reflected prevention of fatty liver formation on $\mathrm{CCl}_{4}$ toxicity. On other hand, weight gain was restricted in LFE treated group as compared to control (untreated) groups (Table 2), for which no definite explanation could be made; and it may be due to presence of some anti-diabetic and anti obesity compounds in LFE.

It is known that in case of extensive hepatic damages, enzymes, like AST and ALT, leave the confinement (within liver tissue) and escape into the circulatory system $[44,45]$. Hence, we have studied the levels of AST and ALT in the serum of the diseased mice compared to the untreated control. Serum AST and ALT levels were found to increase markedly in $\mathrm{CCl}_{4}$ intoxicated mice clearly indicating altered permeability of membranes and hepatotoxicity. Interestingly, the level of AST and ALT were significantly reduced by administration of LFE (Table 3). Thus it was revealed that LFE can increase the structural integrity/stabilization of plasma membrane, which also supported the in-vitro erythrocyte membrane stabilizing activity. Moreover, restoration of structural cell integrity in case of treatment with LFE was supported by histology (by comparing the histological sections, Fig. 3). To understand more about the hepatoprotective effect rendered by LFE, the total protein concentration was measured. Total protein level, which came down, in $\mathrm{CCl}_{4}$ intoxicated mice was partially restored by treatment with LFE. The role of antioxidant activities of LFE in vivo was studied by measuring activities of antioxidant enzymes catalase (CAT) and the levels of GSH and TBARS in the liver. TBARS (markers of lipid peroxidation) is used as a main marker of hepatocellular injury [46]. Moreover, peroxidation of polyunsaturated fatty acids at the cell membrane leads to a cytotoxic by-product, malondialdehyde (MDA). During oxidative stress in liver, the amount of MDA determines the extent of oxidative damage [47]. A lower MDA value in liver tissue of mice indicated a stronger protective activity in samples. Our results have shown higher concentration of $\mathrm{MDA}$ in $\mathrm{CCl}_{4}$ treated group while silymerin or LFE (High dose) group significantly reversed these changes through reduction of lipid peroxidation and decreased production of free radical derivatives. This inference was substantiated by the observed decreased level of TBARS. GSH (non-enzymatic antioxidants) is the major non-protein thiol that plays a vital role in maintaining the body's antioxidant defence mechanism $[48,49]$. It was found that the level of GSH in the liver dropped down in $\mathrm{CCl}_{4}$ intoxicated mice. It is of general perception that accessibility of the liver cells to potential antioxidant molecules may prevent gross depletion of GSH to save the organ from destruction by free radical assault. In our case, perhaps, feeding of LFE has probably played an important role in restoring the normal intracellular GSH level. Catalase is an antioxidant enzyme which promotes the degradation of $\mathrm{H}_{2} \mathrm{O}_{2}$ into water and oxygen [50]. Inhibition of enzymatic activities like catalase activity cause accumulation of superoxide radical and $\mathrm{H}_{2} \mathrm{O}_{2}$, which attenuates a cascade of free radical formation. Catalase was found to be increased in LFE (High Dose) or silymerin treated group compared to $\mathrm{CCl}_{4}$ treated group (Fig $2 \mathrm{a}$ and b). This restoration of catalase activity in LFE indicated the potential of LFE as antioxidant and was thus comparable to the known antioxidant, silymerin. These findings have clearly indicated that LFE is capable of protecting the liver by means of improving the enzymatic and non-enzymatic antioxidant defense systems, thus significantly reducing 
the generation of in vivo free radicals activated by $\mathrm{CCl}_{4}$. Histopathological observations have provided phenotypic support in favour of LFE's hepato-protective role in curbing the intensity of damage done by $\mathrm{CCl}_{4}$ intoxication. The occurrence of various signs of liver injury (Additional file 3: Table S1) confirmed extensive hepatic tissue damage in $\mathrm{CCl}_{4}$ group. $\mathrm{CCl}_{4}$ intoxication led to tissue degeneration in liver, which was clear from prominent signs of necrosis. Silymarin and LFE administration demonstrated regeneration of healthy liver tissue with much lesser signs of injury as compared to $\mathrm{CCl}_{4}$ treated group. The microscopy has enabled to distinguish between prominent nucleus containing organized hepatocytes (control) and the deformed nucleus in ameboid overlapped hepatocytes observed in $\mathrm{CCl}_{4}$ treated mice's liver (Fig 3). Restoration of tissue integrity (tight packed cells) was also observed in Silymarin or LFE group. The fatty infiltrations, due to lipid peroxidation, were prominent in $\mathrm{CCl}_{4}$ group, but found lower in silymerin or LFE (High Dose) treated ones. Nevertheless, treatment with LFE demonstrated prominent restoration in hepatocytes. The reduced cytoplasm vacuolization, mononuclear infiltration, prevention of necrosis, and normalized sinusoidal spaces established the hepatoprotective potential of LFE in recovering normal hepatic histoarchitecture.

The antioxidant components present in the LFE was correlated with GCMS data (Additional file 5: Figure S5). The phytochemicals, sitosterol, 1,2,3-benzenetriol (pyrogallol), 3-tert-butyl-4-hydroxyanisole (also known as 3-BHA), syringic acid, oxazolidine-2, 4-dione, 9,12- Octadecadienoic acid and furan-2- carboxylic acid-3-methyl- trimethyl silyl ester identified from the GCMS data (Table 4) have reported antioxidant activities [51-56]. Sitosterol has antihepatotoxic activities which normalizes serum transminase and hepatic antioxidant enzymes in hepato-compromised animals [55]. There may be some more phytochemicals (remained in the GCMS data beyond the known ones) in LFE which are yet to be identified as hepatoprotective agents. In one of our previous reports, it was shown that multiple constituents of a PPE may act synergistically or additively to affect the biological system [57]. There are also other reports on using combination of compounds to gain higher therapeutic effectiveness over singly administered compound(s) [58]. Based on this philosophy, we propose the therapeutic prospect of the flower extract of Lagerstroemia speciosa (L.) Pers in treating liver damages (Additional file 2: Figure S2).

\section{Conclusion}

This study has revealed the antioxidant activity of $L$. speciosa flower extract (LFE), more comprehensibly, by conducting in-vivo studies in addition to in vitro tests. LFE can scavenge or neutralize free radicals of different origin and chelate ferrous ion. There was no toxic effect of LFE on murine spleenocytes and human MCF7 and HepG2 cell lines. The in-vivo tests have indicated that feeding of LFE has several manifestations, like reduction of MDA level, increase in GSH level, and restoration of catalase in $\mathrm{CCl}_{4}$ intoxicated mice, to reverse liver damage to a considerable extent. Furthermore, GCMS analyses have confirmed the presence of various compounds reported as potential antioxidant. These compounds may have contributed towards protection against damages inflicted by free radicals. Summing up all the properties shown by LFE, L. speciosa flowers could be a promising candidate as functional food, obviously after satisfying FDA recommendations. The fact remains that even in the face of rapid urbanization, majority of Indians live in the villages. There are several tribal pockets. Liver damages (both alcoholic and non-alcoholic damaged liver patients are innumerable) are rampant among the rural people. Popularizing such drink which people themselves can prepare will be beneficial to the society at large (Additional file 2: Figure S2).

\section{Additional files}

\section{Additional file 1: Figure S1. Tree view and flowers of Lagerstroemia speciosa (a) L. speciosa in full bloom in the month of March 2014 (b) Flowers of L. speciosa (DOCX $289 \mathrm{~kb})$ \\ Additional file 2: Figure S2. Graphical Abstract of the prospective development of a health drink from flower extract of Lagerstroemia speciosa (DOCX $522 \mathrm{~kb})$}

Additional file 3: Table S1. Comparative scoring of liver histology parameters of the $\mathrm{CCl}_{4}$ induced mice (injured liver) with control (untreated) and treated (LFE). (DOCX $11 \mathrm{~kb}$ )

Additional file 4: Table S4 Photomicrographs of the histological examination of livers samples. (A) Control group demonstrated, normal liver architecture (magnification of 100X); (B) $\mathrm{CCl}_{4}$ group liver demonstrated fibrosis (FB) (magnification of 100X) (C) and (D) $\mathrm{CCl}_{4}$ group liver demonstrated fibrosis (FB) (magnification of 400X) (DOCX 178 kb)

Additional file 5: Figure S5: FTIR spectra of flower extract of Lagerstroemia speciosa (DOCX $44 \mathrm{~kb}$ )

Additional file 6: Figure S6. EDS spectra of ethanolic flower extract of Lagerstroemia speciosa (DOCX $58 \mathrm{~kb}$ )

Additional file 7: Figure S7. GCMS spectra of lyophilysed ethanolic flower extract of Lagerstroemia specios (DOCX $125 \mathrm{~kb}$ )

\section{Acknowledgements}

Authors are thankful to Sophisticated Test and Instument Centre, SAIF, Cochin University, for EDS spectra. Authors are thankful to Dibakar

Choudhury and Prof. Abhaya Prasad Das, Taxonomy \& Environmental Biology Laboratory, Department of Botany, University of North Bengal for identification of plant. Authors also wish to thank Vivek Kumar Ranjan for his active support. Authors are also thankful to Mr.Jayjit Sarkar, Department of English, North Bengal St. Xavier's College, for his generous help in proofreading the manuscript.

Funding

The authors did not get any fund from any organisation for this study.

\section{Availability of data and materials}

As no sequence data whatsoever is in the manuscript, there is no question of getting any accession number from the public databases, which renders availability of data. All datasets presented in additional files are of public usages. 


\section{Authors' contributions}

Conceived and designed the experiments: RC, AKN, and TKC. Performed the experiments: BKT, SD, PD, MH, AK, and SB. Analyzed the data: RC, AKN, TKC, BKT, SD, PD. Contributed reagents/materials/analysis tools: RC and AK. The paper was written by RC, BKT, and SD. All authors read and approved the final manuscript.

\section{Competing interests}

The authors declare that they have no competing interests.

\section{Consent for publication}

Human volunteers are not included in this study, so, their consent is not applicable. All the authors have given their consent for this publication.

\section{Ethics approval and concent to participate}

All experiments were approved by the ethical committee University of North Bengal (NO.840/ac/04 CPCSEA; date: 15.09.2010).

\section{Author details}

'Department of Biotechnology, Omics Laboratory, University of North Bengal, Darjeeling, West Bengal 734013, India. ${ }^{2}$ Department of Microbiology, North Bengal St. Xavier's College, Rajganj, Jalpaiguri 735135, India. ${ }^{3}$ Department of Zoology, Cellular Immunology Laboratory, University of North Bengal, Darjeeling, West Bengal 734013, India. ${ }^{4}$ Department of Chemistry, University of North Bengal, Darjeeling, West Bengal 734013, India. ${ }^{5}$ ANMOL, Department of Biotechnology, University of North Bengal, Darjeeling, West Bengal 734013, India.

\section{Received: 2 June 2016 Accepted: 22 November 2016}

\section{Published online: 18 January 2017}

\section{References}

1. Orwa C, Mutua A, Kindt R, Jamnadass R, Simons A. Lagerstroemia speciosa. Agroforestree Database a tree reference and selection guide version 4.0. 2009:5. www.worldagroforestry.org/treedb2/AFTPDFS/Lagerstroemia_ speciosa.pdf. Accessed 07 Dec 2016

2. Suzuki Y, Hayashi K, Sukabe I, Kakuda T. Effects and mode of action of banaba (Lagerstroemia speciosa L.) leaf extracts on postprandial blood glucose in rats. Japan Soc Nutri and Food Sci. 2001;54:131-37.

3. Unno T, Sakane I, Masumizu T, Kohno M, Kakuda T. Antioxidant activity of water extracts of Lagerstroemia speciosa leaves. Biosci Biotech Biochem. 1997;61:1772-4.

4. Ambujaksh HRI, Surendra V, Haribabu T, Goli D. Antibacterial activity of leaves of Lagerstroemia speciosa (L). Pers J Pharma Res. 2009:2:1028.

5. Thambi P, Sabu MC, Chungath J. Hepatoprotective and free radical scavenging activities of Lagerstroemia speciosa Linn. leaf extract. Orient Pharma Exp Med. 2009;9:225-31.

6. Saumya SM, Basha PM. Antioxidant effect of Lagerstroemia speciosa Pers (Banaba) leaf extract in streptozotocin-induced diabetic mice. Indian J Exp Biol. 2011;49:125-31.

7. Junaid S, Rakesh KN, Dileep N, Poornima G, Kekuda PTR, Mukunda S. Total phenolic content and antioxidant activity of seed extract of lagerstroemia speciosa. L Chem Sci Trans. 2013;2(1):75-80.

8. Chan EWC, Tan LN, Wong SK. Phytochemistry and pharmacology of lagerstroemia speciosa: a natural remedy for diabetes. Int I Herbal Med. 2014;2:100-5.

9. Prabhu W, Chidambaranathan N, Nalini G, Venkataraman S, Jayaprakash S, Nagarajan M. Evaluation of anti-fibrotic effect of Lagerstroemia speciosa (L) Pers on carbon tetrachloride induced liver fibrosis. Curr Pharm Res. 2010; 1(1):7-12.

10. Kaisoona O, Siriamornpuna S, Weerapreeyakulb N, Meesoc N. Phenolic compounds and antioxidant activities of edible flowers from Thailand. J Funct Foods. 2011;3:88-99.

11. Philippine Herbal plant and their uses. www.stuartxchange.org/Banaba.html. Accessed 23Aug 2014

12. Philippine Medicinal plants. www.stuartxchange.org/Banaba.html. Accessed 4 Jan 2014.

13. Anderson D. Antioxidant defences against reactive oxygen species causing genetic and other damage. Mutat Res. 1996;350:103-08.
14. Dina A, Nassima C, Meriem B, Karima A, Hakima L, Hania B. Antioxidant capacity and phenol content of selected Algerian medicinal plants. Food Chem. 2009;112:303-09.

15. Moure A, Cruz JM, Franco D, Dominguez JM, Sineiro J, Dominguez H, et al. Natural antioxidants from residual sources. Food Chem. 2001;72:145-71.

16. Mossa A-TH, Heikal TM, Belaiba M, Raoelison EG, Ferhout H, Bouajila J. Antioxidant activity and hepatoprotective potential of Cedrelopsis grevei on cypermethrin induced oxidative stress and liver damage in male mice. BMC Complement Altern Med. 2015;15:251.

17. Vladimir-Knezevic S, Cvijanovic O, Blazekovic B, Kindl M, Stefan MB, Domitrovic R. Hepatoprotective effects of Micromeria croatica ethanolic extract against $\mathrm{CCl}_{4}$-induced liver injury in mice. BMC Complement Altern Med. 2015:15:233

18. Asadi-Samani M, Kafash-Farkhad N, Azimi N, Fasihi A, Alinia-Ahandani E, Rafieian-Kopaei M. Medicinal plants with hepatoprotective activity in Iranian folk medicine. Asian Pac J Trop Biomed. 2015;5:146-57.

19. Kameshwaran S, Kothai AR, Jothimanivannan C, Senthilkumar R. Evaluation of hepatoprotective activity of Tecoma stans Flowers. Pharmacologia. 2013;4:236-42.

20. Abba PO, Lydie B, Gervais MM, Sekou D, Tanoh HK, Allico JD, Jean DN. Hepatoprotective and antioxidant activities of Hibiscus sabdariffa petal extracts in Wistar rats. Int J Basic Clin Pharmacol. 2014;3(5):774-80.

21. El Mallah MM, Mohamed RA. Hepatoprotective effect of calendula officinalis Linn (asteraceae) flowers against CCL - induced hepatotoxicity in rats. World Appl Sci J. 2015;33(12):1949-59.

22. Omidi A, Riahinia N, Montazer Torbati M, Behdani M. Hepatoprotective effect of Crocus sativus (saffron) petals extract against acetaminophen toxicity in male Wistar rats. Avicenna J Phytome. 2014;4:330-36.

23. Hazra B, Sarkar R, Biswas S, Mandal N. Comparative study of the antioxidant and reactive oxygen species scavenging properties in the extracts of the fruits of Terminalia chebula, Terminalia belerica and Emblica officinalis. BMC Complement Altern Med. 2010;10:20.

24. Mahakunakorn $\mathrm{P}$, Tohda M, Murakami Y, Matsumoto K, Watanabe $\mathrm{H}$ Antioxidant and free radical-scavenging activity of Choto-san and its related constituents. Biol Pharm Bull. 2004;27:38-46.

25. Dey P, Dutta S, Chaudhuri TK. Evaluation of erythrocyte membrane stabilizing activity, haemolytic activity and cytotoxic effect of the areal tubers of dioscorea alataof north-eastern region of India. J Pharmaceu Sci Inno. 2013:2(3)1-4.

26. Denizot F, Lang R. Rapid colorimetric assay for cell growth and survival. Modification to the tetrazolium dye procedure giving improved sensitivity and reliability. J Immunol Methods. 1986;89:271-77.

27. Venkateshwarlu E, Raghuram RA, Goverdhan P, Rani S, Jayapal RG. In vitro and in vivo antioxidant activity of methanolic extract of solena amplexicaulis (whole plant). Int J Pharm Biol Sci. 2011;1:522-33.

28. Ellman GC. Tissue sulfhydryl groups. Arch Biochem Biophys. 1959;82:70-7.

29. Aruoma Ol. Methodological consideration for characterization for potential antioxidant actions of bioactive components in plants foods. Mutat Res. 2003;532:9-20

30. Murakami C, Myoga K, Kasai R, Ohtani K, Kurokawat T, Ishibashi S, Dayrit F, Padolina WG, Yamasaki K. Screening of plant constituents for effect on glucose transport activity in Ehrlich ascites tumour cells. Chem Pharma Bull. 1993;41:2129-31.

31. Klein G, Kim J, Himmeldirk K, Cao Y, Chen X. Antidiabetes and anti-obesity activity of Lagerstroemia speciosa. Evid Based Complement Altern Med. 2007:4:401-07.

32. Pavithra GM, Siddiqua S, Naik AS, Prashith KTR, Vinayaka KS. Antioxidant and antimicrobial activity of flowers of Wendlandia thyrsoidea, Olea dioica, Lagerstroemia speciosa and Bombax malabaricum. J Appl Pharmaceutical Sci. 2013;3:114-20

33. Anatolovich M, Prenzler PD, Patsalides E, McDonald S, Robards K. Methods for testing antioxidant activity. Analyst. 2002;127(1):183-98.

34. Jayaprakasha GK, Negi PS, Sikder S, Mohanrao LJ, Sakariah KK. Antibacterial activity of Citrus reticulate peel extracts. J Bioscience. 2000;55:1030-34

35. Bravo L. Polyphenols: chemistry, dietary sources, metabolism and nutritional significance. Nutr Rev. 1998;56:317-33.

36. Lobo V, Phatak A, Chandra N. Free radicals and functional foods: impact on human health. Pharmacogn Rev. 2010;4:118-126H.

37. Mihailovic V Mihailovic M Uskokovic A, Arambasic J, Misic D, Stankovic V, et al. Hepatoprotective effects of Gentiana asclepiadea L. extracts against carbon tetrachloride induced liver injury in rats. Food Chem Toxicol. 2012 52:83-90. 
38. Kaplowitz NTY, Simon FR, Stolz A. Reactive oxygen species, aging, and antioxidative nutraceuticals drug induced hepatotoxicity. Ann Intern Med. 1986;104:826-39.

39. Suryanarayana $V$, Vulimiri $A B$, Babasaheb $S$. The potential of metabolomic approaches for investigating mode(s) of action of xenobiotics: Case study with carbon tetrachloride. Mutat Res-Genet Toxicol E M. 2011;722:147-53.

40. Kren V, Walterova D. Silybin and silymarin - New effects and applications. Biomed Pap. 2005;149:29-41.

41. Shaker E, Mahmoud H, Mnaa S. Silymarin, the antioxidant component and Silybum marianum extracts prevent liver damage. Food Chem Toxicol. 2010; 46:803-06.

42. Khan RA, Khan MRS, Sahreen S. CCl4-induced hepatotoxicity: protective effect of rutin on p53, CYP2E1 and the antioxidative status in rat. BMC Complement Altern Med. 2012;12:178.

43. Cheeseman KH, Albano EF, Tomasi A, Slater TF. Biochemical studies on the metabolic activation of halogenated alkanes. Envir Hlth Perspec. 1985;64:85-101

44. Coballase-Urrutia E, Pedraza-Chaverri J, Cardenas-Rodriguez N, HuertaGertrudis B, Garcia-Cruz M.E, Ramirez-Morales A, et al., 201; Hepatoprotective effect of acetonic and methanolic extracts of Heterotheca inuloides against CCl(4)- induced toxicity in rats. Exp. Toxicol. Pathol. 2011;63:363-70.

45. Raja S, Ahamed KF, Kumar V, Mukherjee K, Bandyopadhyay A, Mukherjee PK Antioxidant effect of Cytisus scoparius against carbon tetrachloride treated liver injury in rats. J Ethnopharmacol. 2007;109:41-7.

46. Valko M, Leibfritz D, Moncol J, Cronin MT, Mazur M, Telser J. Free radicals and antioxidants in normal physiological functions and human disease. Int $J$ Biochem Cell Biol. 2007;39:44-84.

47. Ohkawa H, Ohishi N, Yagi K. Assay for lipid peroxides in animal tissues by thiobarbituric acid reaction. Anal Biochem. 1979;95:351-8.

48. He J, Huang B, Ban X, Tian J, Zhu L, Wang Y. In vitro and in vivo antioxidant activity of the ethanolic extract from Meconopsis quintuplinervia. J Ethnopharmacol. 2012;141:104-10.

49. Skrzydlews E, Farbiszewski R. Antioxidant status of liver, erythrocytes, and blood serum of rats in acute methanol intoxication. Alcohol. 1997; 14:431-37.

50. Gaetani G, Ferraris A, Rolfo M, Mangerini R, Arena S, Kirkman H. Predominant role of catalase in the disposal of hydrogen peroxide within human erythrocytes. Blood. 1996:87:1595-99.

51. Ha YL, Storkson J, Pariza MW. Inhibition of benzo (a)pyrene-induced mouse forestomach neoplasia by conjugated dienoic derivatives of linoleic acid. Cancer Res. 1990;50:1097-101.

52. Sakai A, Miyatab N, Takahashi A. Promoting activity of 3-tert-butyl-4hydroxyanisole (BHA) in BALB/3 T3 cell transformation. Cancer Lett. 1997; 115:213-20.

53. Shankarananth V, Ranganayakulu D, Sridhar C, Rajasekhar KK. Synthesis and antioxidant activity of some oxazolidine dione derivatives. Drug Invent Today. 2012:44:358-59.

54. Mohamed SA, Khan JA. Antioxidant capacity of chewing stick miswak Salvadora persica. BMC Complement Altern Med. 2013;13:40.

55. Singh D, Arya PV, Aggarwal VP, Gupta RS. Evaluation of antioxidant a hepatoprotective activities of Moringa oleifera Lam. leaves in carbon tetrachloride-intoxicated rats. Antioxidants. 2014;3:569-91.

56. Ozturk SSB. Acethylcholinesterase inhibitory potential and antioxidant properties of pyrogallol. J Enzyme Inhib Med Chem. 2015;30:761-66.

57. Ghosh R, Tiwary BK, Kumar A, Chakraborty R. Guava leaf extract inhibits quorum-sensing and Chromobacterium violaceum induced lysis of human hepatoma cells: whole transcriptome analysis reveals differential gene expression. PLoS One. 2014;9(9):e107703.

58. Hudecova A, Kusznierewicz B, Hašplova K, Huk A, Magdolenova Z Miadokova E, Galova E, Dušinska M. Gentiana asclepiadea exerts antioxidant activity and enhances DNA repair of hydrogen peroxide- and silver nanoparticles-induced DNA damage. Food Chem Toxicol. 2012;50:3352-59.

\section{Submit your next manuscript to BioMed Central and we will help you at every step:}

- We accept pre-submission inquiries

- Our selector tool helps you to find the most relevant journal

- We provide round the clock customer support

- Convenient online submission

- Thorough peer review

- Inclusion in PubMed and all major indexing services

- Maximum visibility for your research

Submit your manuscript at www.biomedcentral.com/submit
Biomed Central 